\title{
Alicyclobacillus hesperidum sp. nov. and a related genomic species from solfataric soils of São Miguel in the Azores
}

\author{
L. Albuquerque, ${ }^{1}$ F. A. Rainey, ${ }^{2,3}$ A. P. Chung, ${ }^{1}$ A. Sunna, ${ }^{4}+$ M. F. Nobre, ${ }^{1}$ \\ R. Grote, ${ }^{4}$ G. Antranikian ${ }^{4}$ and M. S. da Costa ${ }^{1}$
}

Author for correspondence: M. S. da Costa. Tel: +351 39 824024. Fax: +351 39826798. e-mail:milton@cygnus.ci.uc.pt

\footnotetext{
1 Centro de Neurociências de Coimbra, Departamento de Zoologia, Universidade de Coimbra, 3004-517 Coimbra, Portugal

2 Deutsche Sammlung von Mikroorganismen und Zellkulturen $\mathrm{GmbH}$, Mascheroder Weg 1, 38124 Braunschweig, Germany

3 Department of Biological Sciences, Louisiana State University, Baton Rouge, LA 70803, USA

4 Technische Mikrobiologie, Technische Universität Hamburg-Harburg, Denickestrasse 15, 21073 Hamburg, Germany
}

\begin{abstract}
Several acidophilic, slightly thermophilic or thermophilic Gram-positive isolates were recovered from solfataric soil at Furnas on the Island of São Miguel in the Azores. Phylogenetic analysis of the 16S rRNA gene sequence showed that these organisms represented two novel species of the genus Alicyclobacillus. Strains FR-11' and FR-1b had an optimum growth temperature of about $50{ }^{\circ} \mathrm{C}$, whereas strains FR-3 and FR-6 ${ }^{\top}$ had an optimum growth temperature of about $60^{\circ} \mathrm{C}$. Biochemical, physiological and chemotaxonomic characteristics did not distinguish isolates FR-3 and FR- $6^{\top}$ from the type strain of Alicyclobacillus acidocaldarius; however, strains FR-11' and FR-1b could be easily distinguished from the type strain of Alicyclobacillus acidoterrestris by the carbon source assimilation pattern and the fatty acid composition. On the basis of the phylogenetic analysis, physiological and biochemical characteristics, and fatty acid composition the name Alicyclobacillus hesperidum is proposed for the species represented by strains FR-11' and FR-1b; a formal name for the new genomic species represented by strains FR-3 and $F R^{-}{ }^{\top}$ is not proposed at this time.
\end{abstract}

Keywords: Alicyclobacillus hesperidum sp. nov., Alicyclobacillus genomic species, Bacteria, thermophiles

\section{INTRODUCTION}

The strictly aerobic, slightly thermophilic or thermophilic bacteria of the genus Alicyclobacillus were initially placed in the genus Bacillus with which they share the characteristic of endospore formation. However, phylogenetic analysis based on sequence comparisons of the $16 \mathrm{~S}$ rRNA gene showed that species of the genus Alicyclobacillus belonged to a distinct line of descent within the low $\mathrm{G}+\mathrm{C}$ Gram-positive lineage of the Bacteria that also included the closely related facultatively autotrophic species of the genus Sulfobacillus (Wisotzkey et al., 1992; Tourova et al., 1994;

\footnotetext{
†Present address: Department of Biological Sciences, Macquarie University, Sydney, NSW 2109, Australia.

The EMBL accession numbers for the 16S rRNA gene sequences of strains FR-11 ${ }^{\top}$, FR-1b, FR-3, FR-6 ${ }^{\top}$ and Alicyclobacillus acidoterrestris DSM $3922^{\top}$ are AJ133633, AJ133632, AJ133634, AJ133635 and AJ133631, respectively.
}

Durand, 1996). The three validly named species of the genus Alicyclobacillus are: Alicyclobacillus acidocaldarius (Darland \& Brock, 1971), Alicyclobacillus acidoterrestris (Deinhard et al., 1987a) and Alicyclobacillus cycloheptanicus (Deinhard et al., 1987b). The species $A$. acidoterrestris and A. cycloheptanicus have optimum growth temperatures of $45-50{ }^{\circ} \mathrm{C}$, whereas A. acidocaldarius has a higher optimum growth temperature of about $60-65^{\circ} \mathrm{C}$. All species have $\mathrm{pH}$ optima for growth of 3.5-4.0, a minimum $\mathrm{pH}$ for growth of about 2.5 and a maximum $\mathrm{pH}$ for growth of approximately $5 \cdot 5$. The most distinctive characteristic of these organisms is, in our view, the presence of $\omega$ cyclohexyl or $\omega$-cycloheptyl fatty acids; the species $A$. acidoterrestris and $A$. acidocaldarius, have large relative proportions of $\omega$-cyclohexyl fatty acids (De Rosa et al., 1971; Oshima \& Ariga, 1975; Hippchen et al., 1981), whereas $\omega$-cycloheptyl fatty acids are the predominant fatty acids of A. cycloheptanicus (Poralla 
\& König, 1983; Allgaier et al., 1985). With the exception of Sulfobacillus spp., which also possess $\omega$ cyclohexyl fatty acids (Dufresne et al., 1996), no other bacterium examined has $\omega$-cyclic fatty acids, thus providing excellent phylogenetic markers for these acidophilic spore-forming bacteria. Strains of the genus Alicyclobacillus have been isolated from solfataric soils within geothermal areas and several nongeothermal soils (Darland \& Brock, 1971; Deinhard et al., 1987a, b). Most of the interest in these organisms revolves around the study of the role of $\omega$-cyclic fatty acids and hopanoids on membrane function (Poralla et al., 1980; Kannenberg et al., 1984), but there is also considerable interest in the biotechnological application of thermostable enzymes derived from $A$. acidocaldarius-like strains (Schwermann et al., 1994).

Recently, several strains of aerobic acidophilic sporeformers were isolated from the solfataric soils at Furnas on the Island of São Miguel in the Azores. Here, the characteristics of these strains are described and an additional species of the genus Alicyclobacillus is proposed, Alicyclobacillus hesperidum sp. nov.

\section{METHODS}

Isolation and bacterial strains. Strains FR-3, FR-6 ${ }^{\mathrm{T}}$, FR-1b and $\mathrm{FR}-11^{\mathrm{T}}$ ( $\mathrm{T}=$ type strain) were isolated from the Furnas area on the Island of São Miguel, the Azores. Soil was resuspended in water, large particles were allowed to sediment and the suspensions were filtered through membrane filters (Gelman type GN-6; pore size $0.45 \mu \mathrm{m}$, diameter $47 \mathrm{~mm}$ ). The filters were placed on the surface of Bacillus acidocaldarius medium (BAM), $\mathrm{pH} 4.0$ solidified with agar (Deinhard et al., 1987a) and the plates were wrapped in plastic bags during incubation. Strains FR-3 and FR-6 ${ }^{\mathrm{T}}$ were isolated from plates incubated at $60{ }^{\circ} \mathrm{C}$, whereas strains FR-1b and FR-11 ${ }^{\mathrm{T}}$ were isolated from plates incubated at $45^{\circ} \mathrm{C}$. Cultures were purified by subculturing and were kept at $-80{ }^{\circ} \mathrm{C}$ in BAM medium containing $15 \%$ glycerol. The type strains of $A$. acidocaldarius (DSM 446 ${ }^{\mathrm{T}}$ ), A. cycloheptanicus (DSM 4006 ${ }^{\mathrm{T}}$ ) and $A$. acidoterrestris (DSM 3922 ${ }^{\mathrm{T}}$ ) were obtained from Deutsche Sammlung Von Mikroorganismen und Zellkulturen $\mathrm{GmbH}$, Braunschweig, Germany.

Morphological, biochemical and tolerance characteristics. Cell morphology and motility were examined by phasecontrast microscopy during the exponential growth phase in BAM medium. Unless otherwise stated, all biochemical and tolerance tests were performed as described previously (Santos et al., 1989; Manaia \& da Costa, 1991) in BAM liquid medium or in BAM agar. The type strain of Alicyclobacillus acidocaldarius and strains FR-3 and FR-6 ${ }^{\mathrm{T}}$ were incubated at $60{ }^{\circ} \mathrm{C}$ whereas the type strain of Alicyclobacillus acidoterrestris and strains FR-1b and FR-1 $11^{\mathrm{T}}$ were incubated at $50{ }^{\circ} \mathrm{C}$ for up to $5 \mathrm{~d}$. Catalase and oxidase activity was examined as described previously (Smibert \& Krieg, 1981). The growth temperature range of the organisms was examined by measuring the turbidity $(610 \mathrm{~nm})$ of cultures incubated in $300 \mathrm{ml}$ metal-capped Erlenmeyer flasks, containing $100 \mathrm{ml}$ BAM medium, adjusted to $\mathrm{pH} 4 \cdot 0$, in a reciprocal water-bath shaker. The $\mathrm{pH}$ range for growth was examined at 60 or $50{ }^{\circ} \mathrm{C}$ in BAM medium with $\mathrm{pH}$ values adjusted by the addition of $1.0 \mathrm{M}$
$\mathrm{H}_{2} \mathrm{SO}_{4}$. All $\mathrm{pH}$ measurements were performed at room temperature.

Single-carbon source assimilation tests were performed in a minimal medium composed of BAM basal salts, to which filter-sterilized ammonium sulfate $\left(0.5 \mathrm{~g}^{-1}\right)$ and the carbon sources $\left(2 \cdot 0 \mathrm{~g}^{-1}\right)$ were added. Yeast extract was added to carbon source assimilation tests of the type strain of Alicyclobacillus acidoterrestris $\left(0 \cdot 01 \mathrm{~g} \mathrm{l}^{-1}\right)$ which required it for growth. Growth of the strains on single carbon sources was examined by measuring the turbidity of cultures incubated at 60 or $50^{\circ} \mathrm{C}$ in $20 \mathrm{ml}$ screw-capped tubes containing $10 \mathrm{ml}$ medium after $5 \mathrm{~d}$ of growth. Positive and negative control cultures were grown in BAM medium and in minimal medium without carbon source, respectively.

Acidification of the medium was examined with API $50 \mathrm{CH}$ test strips (bioMérieux) using BAM basal salts medium, $\mathrm{pH} 4 \cdot 0,0.5 \mathrm{~g}$ yeast extract $1^{-1}, 3.0 \mathrm{~g}$ agar $1^{-1}$ and $0.03 \mathrm{~g}$ bromophenol blue $1^{-1}$. The micro-organisms were resuspended in BAM basal salts corresponding to tube No. 2 of the MacFarland series of standard opacities (Smibert \& Krieg, 1981). These cell suspensions (approx. $5 \mathrm{ml}$ ) were added to $100 \mathrm{ml}$ BAM medium, distributed in the API 50 $\mathrm{CH}$ test strip wells, as recommended by the manufacturer, and incubated at $60^{\circ} \mathrm{C}$ for the type strain of $\mathrm{A}$. acidocaldarius, strains FR-3 and FR- $6^{\mathrm{T}}$, and at $50{ }^{\circ} \mathrm{C}$ for the type strain of $A$. acidoterrestris, FR-1b and FR $-11^{\mathrm{T}}$ for $5 \mathrm{~d}$. The colour change of the medium from blue to yellow was regarded as acidification by metabolism of the carbon source.

Polar lipid, lipoquinone and fatty acid composition. The cultures used for polar lipid analysis were grown in 11 Erlenmeyer flasks containing $200 \mathrm{ml} \mathrm{BAM}$ medium at 60 or $50{ }^{\circ} \mathrm{C}$ in a reciprocal water-bath shaker until the exponential phase of growth. Harvesting of the cultures, extraction of the lipids and single dimensional TLC were performed as described previously (Prado et al., 1988; Donato et al., 1990)

Lipoquinones were extracted from freeze-dried cells and were purified by TLC as described previously (Tindall, 1989). The lipoquinones were separated with a Gilson HPLC by using a reverse-phase (RP18) Spherisorb S50DS2 column and methanol-heptane $(10: 2, \mathrm{v} / \mathrm{v})$ as the mobile phase and were detected at $269 \mathrm{~nm}$.

Cultures for fatty acid analysis were grown on BAM medium plates, in sealed plastic bags submerged in a water bath at 60 or $50{ }^{\circ} \mathrm{C}$ for $24 \mathrm{~h}$. Fatty acid methyl esters were obtained from fresh wet biomass by saponification, methylation and extraction as described previously (Kuykendall et al., 1988). The fatty acid methyl esters were separated using a Hewlett Packard model 5890 GC equipped with an FID fitted with a $5 \%$ phenylmethyl silicone capillary column $(0 \cdot 2 \mathrm{~mm} \times 25$ $\mathrm{m}$; Hewlett Packard). The carrier gas was high-purity $\mathrm{H}_{2}$; the column head pressure was $60 \mathrm{kPa}$; the septum purge was $5 \mathrm{ml} \mathrm{min}-1$; the column split ratio was $55: 1$; and the injection port temperature was $300^{\circ} \mathrm{C}$. The temperature of the oven was programmed at $170-270{ }^{\circ} \mathrm{C}$ at a rate of $5^{\circ} \mathrm{C} \mathrm{min}{ }^{-1}$. Identification and quantification of the fatty acid methyl esters, as well as the numerical analysis of the fatty acid profiles, were performed by using the standard MIS Library Generation Software (Microbial ID).

Determination of mean base composition of DNA and DNA-DNA reassociation studies. The $\mathrm{G}+\mathrm{C}$ content of the overall genome was determined by HPLC as described by Mesbah et al. (1989). DNA for DNA-DNA reassociation 
studies was extracted and purified by the procedure of Marmur (1961). The degree of DNA reassociation was determined spectrophotometrically from the initial renaturation rates, according to De Ley et al. (1970). The renaturation rates were measured in $1 \times \mathrm{SSC}(0 \cdot 15 \mathrm{M} \mathrm{NaCl}$ and $0.015 \mathrm{M}$ trisodium citrate at $\mathrm{pH} 7 \cdot 0$ ), using a Uvikon 940 spectrophotometer (Kontron) equipped with a thermostat-controlled cuvette chamber. The optimal renaturation temperature used in each case was calculated from the $\mathrm{G}+\mathrm{C}$ value (mol \%) (De Ley et al., 1970). Each hybridization experiment was executed at least twice.

16S rRNA gene sequence determination and phylogenetic analyses. The extraction of genomic DNA, PCR amplification of the 16S rRNA gene and sequencing of the purified PCR products were carried out as described previously (Rainey et al., 1996). Sequence reaction products were purified by ethanol precipitation and electrophoresed with a model 373A DNA sequencer or a 310 Genetic Analyzer (Applied Biosystems). The ae2 editor (Maidak et al., 1999) was used to align the 16S rRNA gene sequences obtained in this study with previously determined Alicyclobacillus sequences available from the public databases. The method of Jukes \& Cantor (1969) was used to calculate evolutionary distances. Phylogenetic dendrograms were generated using various treeing algorithms contained in the PHYLIP package (Felsenstein, 1993).

The EMBL accession numbers of the 16S rRNA gene sequences determined in this study are as follows: strain FR$11^{\mathrm{T}}$, AJ133633; strain FR-1b, AJ133632; strain FR-3, AJ133634; strain FR-6 ${ }^{\mathrm{T}}$, AJ133635; and $A$. acidoterrestris DSM 3922 ${ }^{\mathrm{T}}$, AJ133631. The accession numbers and strain designations of the reference $16 \mathrm{~S}$ rRNA gene sequences used in the phylogenetic analyses are as follows: A. acidocaldarius DSM 446 ${ }^{\mathrm{T}}$, X60742; A. cycloheptanicus DSM 4006 ${ }^{\mathrm{T}}$, X51928; Bacillus tusciae DSM 2912 ${ }^{\mathrm{T}}$, Z26933; Sulfobacillus disulfidooxidans SD-11 ${ }^{\mathrm{T}}$, U34974; and Sulfobacillus thermosulfidooxidans VKM B1269 ${ }^{\mathrm{T}}$, Z21979.

\section{RESULTS}

\section{Isolation, and biochemical and physiological characteristics of the strains}

The organisms were isolated from acidic soils within the small solfataric area at Furnas on the Island of São Miguel in the Azores. Enrichments performed at 45 or $60{ }^{\circ} \mathrm{C}$ on BAM agar led to the isolation of several organisms, of which strains FR-1b, FR-11 ${ }^{\mathrm{T}}$, FR-3 and FR $-6^{\mathrm{T}}$ were characterized. Strains FR-1b and FR-1 $11^{\mathrm{T}}$ had optimum growth temperatures (about $50{ }^{\circ} \mathrm{C}$ ) that were very similar to that of the type strain of $A$. acidoterrestris. The optimum and maximum growth temperatures of strains FR-3 and FR-6 ${ }^{\mathrm{T}}$ were about $2-5^{\circ} \mathrm{C}$ lower than that of the type strain of $A$. acidocaldarius, which was very noticeable at supraoptimum growth temperatures. The type strain of $A$. acidocaldarius grows at $70^{\circ} \mathrm{C}$, whereas the Azorean strains did not (Fig. 1). The $\mathrm{pH}$ range for growth of the isolates and the two type strains was similar (Fig. 2).

All the organisms were cytochrome oxidase-negative and catalase was not detected or was weak. Unlike the type strain of $A$. acidoterrestris, strains FR-1b, FR$11^{\mathrm{T}}, \mathrm{FR}-3$ and FR-6 $6^{\mathrm{T}}$ did not require yeast extract or co-factors for growth. All organisms hydrolysed

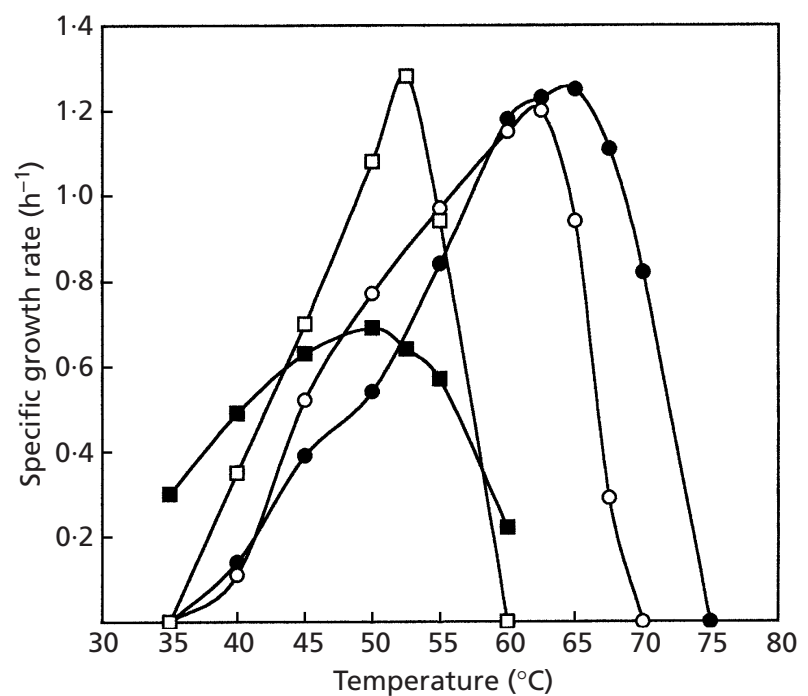

Fig. 1. Effect of temperature on the growth rates of the type strain of $A$. acidocaldarius (O), strain FR- $\sigma^{\top}(O)$, the type strain of $A$. acidoterrestris $(\square)$ and strain $\mathrm{FR}-11^{\top}(\square)$.

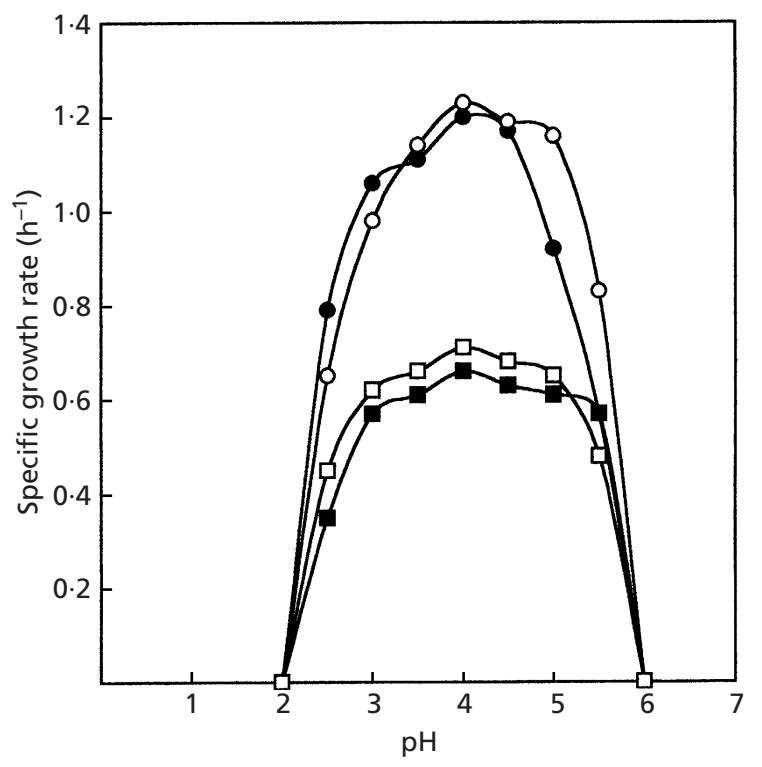

Fig. 2. Effect of $\mathrm{pH}$ on the growth rates of the type strain of A. acidocaldarius $(\mathbf{O})$, strain $F R-6^{\top}(O)$, the type strain of A. acidoterrestris $(\boldsymbol{\square})$ and strain $\mathrm{FR}-11^{\top}(\square)$.

gelatin, hippurate, arbutin and aesculin. A. acidoterrestris did not hydrolyse xylan and hide powder azure. Strains FR-3, FR-6 ${ }^{\mathrm{T}}$ and $A$. acidocaldarius had practically identical single carbon source assimilation patterns, being generally unable to grow on most of the polyols, except glycerol and mannitol. Strains FR-1b and FR $-11^{\mathrm{T}}$ had a radically different single carbon source assimilation pattern from $A$. acidoterrestris; several sugars, amino acids and organic acids, in 
addition to most polyols, were not used for growth. All strains produced acid from virtually the same sugars and sugars derivatives used as carbon sources (Table 1).

\section{Polar lipid, lipoquinone and fatty acid composition}

All strains had virtually identical polar lipid patterns on single dimensional TLC, being composed of two phospholipids, one aminoglycolipid, one glycolipid and a sulfonolipid. The major respiratory quinone was menaquinone 7 . The major fatty acid of all strains was $\omega$-cyclohexyl 17:0 (Table 2). The type strain of $A$. acidocaldarius and the high temperature strains FR-3 and FR $-6^{\mathrm{T}}$ had very similar fatty acid compositions that made them difficult to distinguish from each other. The type strain of $A$. acidoterrestris had very large relative proportions of $\omega$-cyclohexyl 17:0 that reached about $70 \%$ of the total fatty acids; acyl components, other than $\omega$-cyclohexyl 19:0, which reached about $25 \%$ of the total fatty acids, were vestigial or were not detected in this strain. Strains FR$1 \mathrm{~b}$ and FR-1 $11^{\mathrm{T}}$, on the other hand, had lower relative proportions of $\omega$-cyclohexyl fatty acids and higher proportions of branched-chain fatty acids than $A$. acidoterrestris. Anteiso fatty acids reached about $20 \%$ of the total and iso fatty acids reached about $18 \%$ of the total fatty acids in strain FR-1b and FR-11 ${ }^{\mathrm{T}}$.

\section{S rRNA gene sequence based phylogenetic analysis and DNA-DNA reassociation studies}

Almost complete 16S rRNA gene sequences of 14821485 nucleotides in length were determined for the four new isolates and A. acidoterrestris DSM $3922^{\mathrm{T}}$. Phylogenetic analyses based on a data set comprising 1420 unambiguous nucleotides between positions 36 and 1510 [Escherichia coli positions (Brosius et al., 1978)] showed that the new isolates clustered with the previously described species of the genus Alicyclobacillus (Fig. 3). Two of the four strains, strains FR-6 ${ }^{\mathrm{T}}$ and FR-3, shared $99 \cdot 3 \%$ 16S rRNA gene sequence similarity and clustered with $A$. acidocaldarius $(97 \cdot 8-$ $98.0 \%$ similarity). Strains FR-11 $1^{\mathrm{T}}$ and FR-1b had identical 16S rRNA gene sequences and clustered with A. acidoterrestris at $97.7 \%$ similarity.

The distinct species status of strain FR-6 ${ }^{\mathrm{T}}$ was demonstrated by a DNA-DNA reassociation value of $53.3 \%$ with the type strain of A. acidocaldarius. Strain FR-1 $1^{\mathrm{T}}$ had a DNA-DNA reassociation value of $60.6 \%$ with the type strain of $A$. acidoterrestris.

\section{DISCUSSION}

Acidophilic strains of slightly thermophilic or thermophilic spore-forming bacteria appear to be common in solfataric soils. Some of the thermophilic organisms that have growth temperature ranges similar to those of the type strain of A. acidocaldarius, however, may be difficult to distinguish from the type strain of the species. In this study, the only thermo-acidophilic spore-forming strains isolated were, in fact, very similar to A. acidocaldarius. However, the $2 \cdot 0-2 \cdot 2 \%$ $16 \mathrm{~S}$ rRNA gene sequence difference, and the low DNA-DNA reassociation values between strains FR3 and FR $-6^{\mathrm{T}}$ and the type strain of $A$. acidocaldarius clearly show that these strains represent a new genomic species. The only noticeable difference between the two species was the slightly lower optimum and maximum growth temperatures. The biochemical, physiological and chemotaxonomic characteristics of the new species represented by strains FR-3 and FR-6 ${ }^{\mathrm{T}}$ were indistinguishable from those of the type strain of $A$. acidocaldarius. Yet, it is considered that this feature is not sufficient to clearly distinguish strains FR-3 and FR- ${ }^{\mathrm{T}}$ from $A$. acidocaldarius, particularly since only the type strain of the latter species could be examined and a typical phenotype cannot be ascribed for this species. Therefore, the absence of distinct phenotypic characteristics points against proposing a formal name for strains FR-3 and FR-6 ${ }^{\mathrm{T}}$ at this time. Nevertheless, these strains show that genomic species, other than $A$. acidocaldarius, are found in solfataric soils that might be mistaken for the type species of this genus because of similar phenotypic characteristics.

The carbon source assimilation pattern and the fatty acid composition clearly distinguishes strains FR-1b and $\mathrm{FR}-11^{\mathrm{T}}$ from the type strain of $A$. acidoterrestris. Moreover, DNA-DNA reassociation values between A. acidoterrestris and strain FR- $11^{\mathrm{T}}$ and the phylogenetic analysis show that these strains are distinct, but related to $A$. acidoterrestris rather than to A. cycloheptanicus. The 16S rRNA gene sequence similarity values also support the novel species status of these strains. Based on the distinct biochemical and chemotaxonomic characteristics, and the 16S rRNA gene sequence comparisons, the name Alicyclobacillus hesperidum is proposed for strains FR-1 $11^{\mathrm{T}}$ and FR-1b.

\section{Description of Alicyclobacillus hesperidum sp. nov.}

Alicyclobacillus hesperidum (hes.pe.ri'dum. L. fem. plur. N. hesperidum of the Hesperides, mythological figures whom the Greeks believed to have lived at the Western edge of the Earth in a miraculous garden, which we interpret as the Azores).

Rod-shaped cells that are $2 \cdot 1-3 \cdot 9 \mu \mathrm{m}$ long and $0 \cdot 5-$ $0.7 \mu \mathrm{m}$ wide. Gram stain is positive. Cells are nonmotile and terminal spores are formed; sporangia are not swollen. Colonies on BAM medium are $1-2 \mathrm{~mm}$ in diameter after $72 \mathrm{~h}$ of growth and are not pigmented. Growth occurs above $35^{\circ} \mathrm{C}$ and below $60^{\circ} \mathrm{C}$; the optimum growth temperature for strains FR- $11^{\mathrm{T}}$ and $\mathrm{FR}-1 \mathrm{~b}$ is $50-53{ }^{\circ} \mathrm{C}$. The optimum $\mathrm{pH}$ is $3 \cdot 5-4 \cdot 0$; growth does not occur at $\mathrm{pH} 2.0$ or $\mathrm{pH} 6.0$. Strains are 
Table 1. Phenotypic characteristics that distinguish the type strain of $A$. acidocaldarius from strains FR-3 and $\mathrm{FR}-6^{\top}$ after growth at $60^{\circ} \mathrm{C}$ and the type strain of $A$. acidoterrestris from strains FR-1b and FR-11 ${ }^{\top}$ after growth at $50^{\circ} \mathrm{C}$

Strains: 1, A. acidocaldarius; 2, FR-3; 3 , FR-6 $6^{\mathrm{T}} ; 4, A$. acidoterrestris ; 5 , FR-1b; 6, FR-11 ${ }^{\mathrm{T}}$. w, Weakly positive result; - , negative result; + , positive result. All strains: degraded arbutin, aesculin, gelatin, hippurate, Tween 40, Tween 60 and Tween 80; assimilated D-glucose, D-fructose, D-galactose, D-mannose, maltose, sucrose, lactose, D-cellobiose, D-trehalose, D-xylose, L-arabinose, glycerol and D-mannitol; produced acid from glycerol, L-arabinose, D-galactose, D-glucose, D-fructose, D-mannose, mannitol, cellobiose, maltose, lactose, sucrose and trehalose. None of the strains: had cytochrome oxidase activity; degraded elastin and fibrin; produced nitrite; assimilated L-sorbose, L-fucose, L-serine and L-asparagine; produced acid from D-arabinose, L-xylose, D-xylose, adonitol, methyl $\beta$-xyloside, L-sorbose, dulcitol, methyl $\alpha$,D-mannoside, methyl $\alpha$,D-glucoside, $N$-acetyl-glucosamine, amygdalin, arbutin, aesculin, salicin, inulin, melezitose, D-lyxose, Dtagatose, D-fucose, L-fucose, D-arabitol, L-arabitol, gluconate, 2-keto-gluconate and 5-keto-gluconate.

\begin{tabular}{|lcccccc|}
\hline Characteristic & $\mathbf{1}$ & $\mathbf{2}$ & $\mathbf{3}$ & $\mathbf{4}$ & $\mathbf{5}$ & $\mathbf{6}$ \\
\hline Presence of: & & & & & & \\
Catalase & $\mathrm{w}$ & $\mathrm{w}$ & - & $\mathrm{w}$ & $\mathrm{w}$ & - \\
DNase & + & + & + & + & - & - \\
Degradation of: & & & & & & \\
Hide powder azure & + & + & + & - & + & + \\
Starch & + & - & + & - & + & + \\
Xylan & + & + & + & - & + & + \\
Tween 20 & + & + & + & - & + & + \\
Growth in: & & & & & & \\
3\% NaCl & - & - & - & + & + & + \\
4\% NaCl & - & - & - & + & - & - \\
Assimilation of: & & & & & & \\
L-Rhamnose & + & + & + & + & - & - \\
D-Melibiose & + & + & + & - & - & - \\
D-Raffinose & + & + & + & - & + & + \\
D-Ribose & + & + & + & + & - & - \\
D-Arabinose & - & - & - & - & + & + \\
$i$-Erythritol & - & - & - & + & - & - \\
Xylitol & - & - & - & + & - & - \\
D-Arabitol & - & - & - & + & - & - \\
D-Sorbitol & - & - & - & + & - & - \\
Ribitol & - & - & - & + & - & - \\
myo-Inositol & - & + & - & + & - & - \\
Pyruvate & + & + & + & + & - & - \\
Citrate & + & + & + & + & - & - \\
Malate & + & + & + & - & + & - \\
Succinate & + & + & + & + & - & - \\
L-Glutamate & + & + & + & + & - & - \\
L-Proline & + & + & + & + & - & - \\
L-Glutamine & + & + & + & + & - & - \\
Arginine & + & - & + & + & - & - \\
Acid production from & & & & & & \\
Erythritol & - & - & - & + & - & - \\
Ribose & + & + & - & + & - & + \\
Rhamnose & - & + & - & + & - & - \\
Inositol & - & + & - & + & - & - \\
Sorbitol & - & - & - & + & - & - \\
Melibiose & + & + & - & w & w & - \\
D-Raffinose & + & w & + & - & - & - \\
Starch & - & - & - & - & w & w \\
Glycogen & - & - & - & - & + & + \\
Xylitol & - & - & - & + & - & - \\
$\quad \beta$-Gentiobiose & - & - & - & - & - & w \\
D-Turanose & + & + & - & + & + \\
\hline
\end{tabular}

Table 2. Mean fatty acid composition of the type strain of Alicyclobacillus acidocaldarius and strains FR-3 and FR- $6^{\top}$ after growth in medium BAM at $60^{\circ} \mathrm{C}$ and of the type strain of Alicyclobacillus acidoterrestris and strains FR- $1 \mathrm{~b}$ and FR-11 ${ }^{\mathrm{T}}$ after growth in medium BAM at $50^{\circ} \mathrm{C}$

Strains: 1, Alicyclobacillus acidocaldarius; 2, FR-3; 3, FR-6 ${ }^{\mathrm{T}}$; 4, Alicyclobacillus acidoterrestris; 5, FR-1b; 6, FR-11 ${ }^{\mathrm{T}}$.

\begin{tabular}{|lcccccc|}
\hline Fatty acid & \multicolumn{6}{c|}{$\begin{array}{c}\text { Fatty acid composition } \\
\text { (\%) in strains: }\end{array}$} \\
\cline { 2 - 8 } & $\mathbf{1}$ & $\mathbf{2}$ & $\mathbf{3}$ & $\mathbf{4}$ & $\mathbf{5}$ & $\mathbf{6}$ \\
\hline $14: 0$ anteiso & - & - & - & $1 \cdot 0$ & - & - \\
$15: 0$ iso & $2 \cdot 2$ & $0 \cdot 5$ & $1 \cdot 7$ & - & $2 \cdot 6$ & $5 \cdot 4$ \\
$15: 0$ anteiso & - & - & $0 \cdot 8$ & - & $3 \cdot 0$ & $6 \cdot 6$ \\
$16: 0$ iso & $1 \cdot 1$ & - & $1 \cdot 4$ & - & $0 \cdot 8$ & $0 \cdot 9$ \\
$16: 0$ & $0 \cdot 7$ & $0 \cdot 7$ & $0 \cdot 9$ & $1 \cdot 1$ & $2 \cdot 3$ & $2 \cdot 1$ \\
$17: 0$ iso & $10 \cdot 8$ & $2 \cdot 6$ & $8 \cdot 3$ & - & $3 \cdot 1$ & $4 \cdot 9$ \\
$17: 0$ anteiso & $3 \cdot 0$ & $2 \cdot 3$ & $8 \cdot 4$ & $0 \cdot 6$ & $7 \cdot 2$ & $10 \cdot 3$ \\
$\omega-$ Cyclohexyl C17:0 & $48 \cdot 9$ & $53 \cdot 1$ & $51 \cdot 8$ & $71 \cdot 6$ & $66 \cdot 2$ & $56 \cdot 8$ \\
$\omega-$-Cyclohexyl C19:0 & $33 \cdot 3$ & $40 \cdot 9$ & $26 \cdot 7$ & $25 \cdot 8$ & $14 \cdot 8$ & $13 \cdot 3$ \\
\hline
\end{tabular}

cytochrome oxidase-negative and catalase is weak or negative. Yeast extract or growth factors are not required for growth. The major fatty acids are $\omega$ cyclohexyl C17:0 and $\omega$-cyclohexyl C19:0; branchedchain fatty acids are also present in large proportions. Strains do not reduce nitrate to nitrite. Gelatin, hide powder and starch are hydrolysed, but elastin and fibrin are not. Strains FR- $11^{\mathrm{T}}$ and FR-1b utilize many hexoses and disaccharides, but pentoses and polyols, with the exception of mannitol and glycerol, are not utilized as single carbon sources. L-Serine, L-asparagine, L-glutamate, L-glutamine, L-proline and Larginine are not utilized as single carbon sources. Acid is produced from virtually the same sugars that are utilized as single carbon sources. The DNA of strain FR $-11^{\mathrm{T}}$ has a $\mathrm{G}+\mathrm{C}$ content of $53.3 \mathrm{~mol} \%$. This bacterium was isolated from solfataric soils in the Furnas area of the Island of São Miguel, the Azores. Strain FR-1 $1^{\mathrm{T}}$ has been deposited in the Deutsche Sammlung von Mikroorganismen und Zellkulturen, Braunschweig, Germany as strain DSM $12489^{\mathrm{T}}$. Strain FR-1b (=DSM 12766) is an additional strain of this species.

\section{Description of Alicyclobacillus genomic species 1}

Alicyclobacillus species 1 strains form rod-shaped cells that are $2 \cdot 1-4 \cdot 2 \mu \mathrm{m}$ long and $0 \cdot 5-0 \cdot 8 \mu \mathrm{m}$ wide. Gram stain is positive. The cells are non-motile and terminal spores are formed. Sporangia are not swollen. Colonies on BAM medium are 1-2 $\mathrm{mm}$ in diameter after $72 \mathrm{~h}$ of growth and are not pigmented. Growth occurs above $40{ }^{\circ} \mathrm{C}$ and below $70^{\circ} \mathrm{C}$; the optimum growth temperature for strains FR-3 and FR $-6^{\mathrm{T}}$ is $60-63{ }^{\circ} \mathrm{C}$. The 


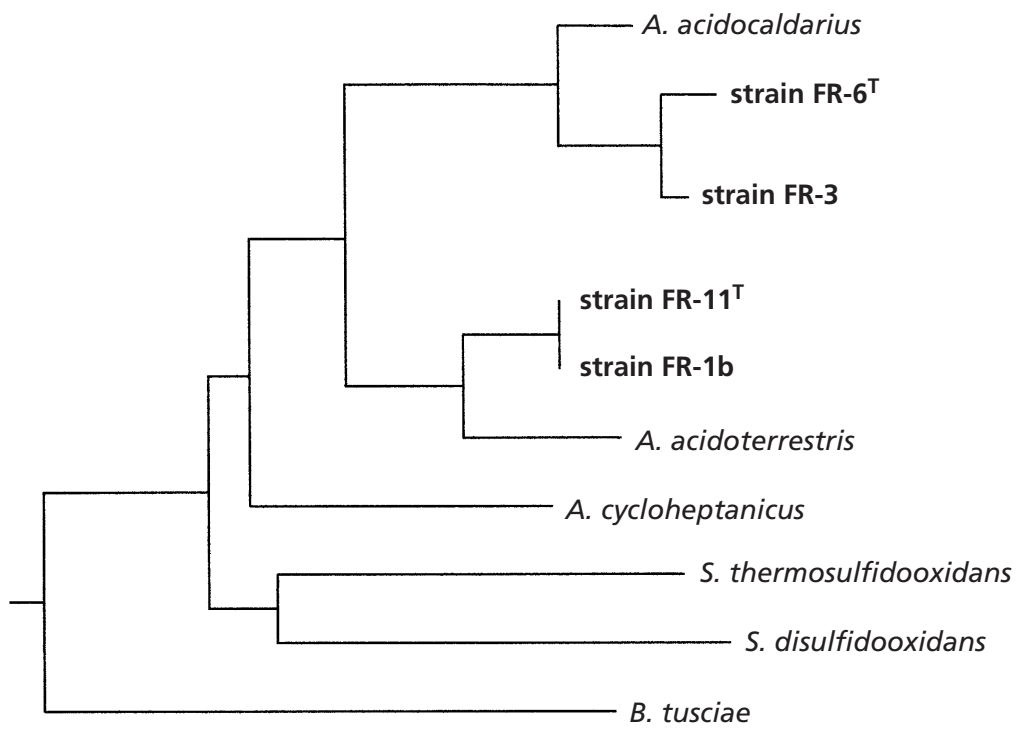

$5 \cdot 0$
Fig. 3. $16 \mathrm{~S}$ rRNA gene sequence based neighbour-joining phylogenetic tree showing the position of the new isolates within the cluster comprising the Alicyclobacillus species and their closest relatives. The position of the root was determined by the inclusion of Bacillus subtilis as an outgroup sequence. Scale bar, 5 inferred nucleotide substitutions per 100 nucleotides. optimum $\mathrm{pH}$ is $3 \cdot 5-4.0$; growth does not occur at $\mathrm{pH} 2.0$ or $\mathrm{pH} 6 \cdot 0$. Strains are cytochrome oxidasenegative and catalase is weak or negative. Yeast extract or growth factors are not required for growth. The major fatty acids are $\omega$-cyclohexyl $\mathrm{C} 17: 0$ and $\omega$ cyclohexyl C19:0; branched-chain fatty acids are also present. Strains do not reduce nitrate to nitrite. Gelatin and hide powder are hydrolysed, but elastin and fibrin are not. Strain FR-3 does not hydrolyse starch. Strains FR-3 and FR-6 ${ }^{\mathrm{T}}$ utilize many hexoses and disaccharides, but pentoses and polyols, with the exception of mannitol and glycerol, are not utilized as single carbon sources. Several amino acids are utilized as single carbon sources. Acid is produced from virtually the same sugars that are utilized as single carbon sources. The DNA of strain FR-6 $6^{\mathrm{T}}$ has a $\mathrm{G}+\mathrm{C}$ content of $60.3 \mathrm{~mol} \%$. This bacterium was isolated from solfataric soils in the Furnas area of the Island of São Miguel, the Azores. Strain FR-6 ${ }^{\mathrm{T}}$ has been deposited in the Deutsche Sammlung von Mikroorganismen und Zellkulturen, Braunschweig, Germany as strain DSM $11984^{\mathrm{T}}$. Strain FR-3 (= DSM 11983) is an additional strain of this species.

\section{ACKNOWLEDGEMENTS}

This work was supported in part by the European Community Biotech Programme (Extremophiles as Cell Factories) Contract No. BIO4-CT96-0488 and PRAXIS XXI Program (PRAXIS/PCNA/BIO/46/76), Portugal. L.A. was supported by a PRAXIS XXI scholarship (PRAXIS XXI/BM/12769/97). We also thank J. Burghardt (DSM, Germany) for the DNA-DNA reassociation values.

\section{REFERENCES}

Allgaier, H., Poralla, K. \& Jung, G. (1985). $\omega$-Cycloheptyl- $\alpha$ hydroxyundecanoic acid, a new fatty acid from a thermoacidophilic Bacillus species. Liebigs Ann Chem 1985, 378-382.

Brosius, J., Palmer, M. L., Kennedy, P. J. \& Noller, H. F. (1978). Complete nucleotide sequence of the 16S ribosomal RNA gene from Escherichia coli. Proc Natl Acad Sci USA 75, 4801-4805.

Darland, G. \& Brock, T. D. (1971). Bacillus acidocaldarius sp. nov., an acidophilic thermophilic spore-forming bacterium. J Gen Microbiol 67, 9-15.

Deinhard, G., Blanz, P., Poralla, K. \& Altan, E. (1987a). Bacillus acidoterrestris sp. nov., a new thermotolerant acidophile isolated from different soils. Syst Appl Microbiol 10, 47-53.

Deinhard, G., Saar, J., Krischke, W. \& Poralla, K. (1987b). Bacillus cycloheptanicus sp. nov., a new thermoacidophile containing $\omega$ cycloheptane fatty acids. Syst Appl Microbiol 10, 68-73.

De Ley, J., Cattoir, H. \& Reynaerts, A. (1970). The quantitative measurement of DNA hybridization from renaturation rates. Eur J Biochem 12, 133-142.

De Rosa, M., Gambacorta, A., Minale, L. \& Bu'Lock, J. D. (1971). Cyclohexane fatty acids from a thermophilic bacterium. Chem Commun 1971, 1334.

Donato, M. M., Seleiro, E. A. \& da Costa, M. S. (1990). Polar lipid and fatty acid composition of strains of the genus Thermus. Syst Appl Microbiol 13, 234-239.

Dufresne, S., Bousquet, J., Boissinot, M. \& Guay, R. (1996). Sulfobacillus disulfidooxidans sp. nov., a new acidophilic, disulfide-oxidizing, Gram-positive, spore-forming bacterium. Int $J$ Syst Bacteriol 46, 1056-1064.

Durand, P. (1996). Primary structure of the 16S rRNA gene of Sulfobacillus thermosulfidooxidans by direct sequencing of PCR amplified gene and its similarity with that of other moderately thermophilic chemolithotrophic bacteria. Syst Appl Microbiol 19, 360-364. 
Felsenstein, J. (1993). PHYLIP (phylogenetic inference package), version 3.5.1. Seattle: Department of Genetics, University of Washington.

Hippchen, B., Röll, A. \& Poralla, K. (1981). Occurrence in soil of thermo-acidophilic bacilli possessing $\omega$-cyclohexane fatty acids and hopanoids. Arch Microbiol 129, 53-55.

Jukes, T. H. \& Cantor, C. R. (1969). Evolution of protein molecules. In Mammalian Protein Metabolism, vol. 3, pp. 21-132. Edited by H. N. Munro. New York: Academic Press.

Kannenberg, E., Blume, A. \& Poralla, K. (1984). Properties of $\omega$ cyclohexane fatty acids in membranes. FEBS Lett 172, 331-334.

Kuykendall, L. D., Roy, M. A., O’Neil, J. J. \& Devine, T. E. (1988). Fatty acids, antibiotic resistance, and deoxyribonucleic acid homology groups of Bradyrhizobium japonicum. Int J Syst Bacteriol 38, 358-361.

Maidak, B. L., Cole, J. R., Parker, C. T. \& 11 other authors (1999). A new version of the RDP (Ribosomal Database Project). Nucleic Acids Res 27, 171-173.

Manaia, C. M. \& da Costa, M. S. (1991). Characterization of halotolerant Thermus isolates from shallow marine hot springs on S. Miguel, Azores. J Gen Microbiol 137, 2643-2648.

Marmur, J. (1961). A procedure for the isolation of deoxyribonucleic acid from microorganisms. J Mol Biol 3, 208-218.

Mesbah, M., Premachandran, U. \& Whitman, W. B. (1989). Precise measurement of the $\mathrm{G}+\mathrm{C}$ content of deoxyribonucleic acid by high-performance liquid chromatography. Int J Syst Bacteriol 39, 159-167.

Oshima, M. \& Ariga, T. (1975). $\omega$-Cyclohexyl fatty acids in acidophilic thermophilic bacteria. J Biol Chem 250, 6963-6968.

Poralla, K. \& König, W. A. (1983). The occurrence of $\omega$ cycloheptane fatty acids in a thermo-acidophilic bacillus. FEMS Microbiol Lett 16, 303-306.

Poralla, K., Kannenberg, E. \& Blume, A. (1980). A glycolipid containing hopane isolated from the acidophilic, thermophilic
Bacillus acidocaldarius, has a cholesterol-like function in membranes. FEBS Lett 113, 107-110.

Prado, A., da Costa, M. S. \& Madeira, V. M. C. (1988). Effect of growth temperature on the lipid composition of two strains of Thermus sp. J Gen Microbiol 134, 1653-1660.

Rainey, F. A., Ward-Rainey, N., Kroppenstedt, R. M. \& Stackebrandt, E. (1996). The genus Nocardiopsis represents a phylogenetically coherent taxon and a distinct actinomycete lineage: proposal of Nocardiopsaceae fam. nov. Int $J$ Syst Bacteriol 46, 1088-1092.

Santos, M. A., Williams, R. A. D. \& da Costa, M. S. (1989). Numerical taxonomy of Thermus isolates from hot springs in Portugal. Syst Appl Microbiol 12, 310-315.

Schwermann, B., Pfau, K., Liliensiek, B., Schleyer, M., Fischer, T. \& Bakker, E. P. (1994). Purification, properties and structural aspects of a thermoacidophilic $\alpha$-amylase from Alicyclobacillus acidocaldarius ATCC 27009. Insight into acidostability of proteins. Eur J Biochem 226, 981-991.

Smibert, R. M. \& Krieg, N. R. (1981). General characterization. In Manual of Methods for General Bacteriology, pp. 411-442. Edited by P. Gerhardt, R. G. E. Murray, R. N. Costilow, E. W. Nester, W. A. Wood, N. R. Krieg \& G. B. Phillips. Washington, DC: American Society for Microbiology.

Tindall, B. J. (1989). Fully saturated menaquinones in the archaebacterium Pyrobaculum islandicum. FEMS Microbiol Lett 60, 251-254.

Tourova, T. P., Poltoraus, A. B., Lebedeva, I. A., Tsaplina, I. A., Bogdanova, T. I. \& Karavaiko, G. I. (1994). 16S ribosomal RNA (rDNA) sequence analysis and phylogenetic position of Sulfobacillus thermosulfidooxidans. Syst Appl Microbiol 17, 509-512.

Wisotzkey, J. D., Jurtshuk, J. R. P., Fox, G. E., Deinhard, G. \& Poralla, K. (1992). Comparative sequence analyses on the $16 \mathrm{~S}$ rRNA (rDNA) of Bacillus acidocaldarius, Bacillus acidoterrestris, and Bacillus cycloheptanicus and proposal for creation of a new genus, Alicyclobacillus gen. nov. Int J Syst Bacteriol 42, 263-269. 